\title{
Fluoride Concentration in Drinking Water of Lucknow City, India: A Case Study
}

\author{
Vartika Rai* and Munna Singh \\ Department of Botany, University of Lucknow, India
}

*Corresponding author: Vartika Rai, Department of Botany, University of Lucknow, India, Tel: 0522-2740086; E-mail: vartikarai@rediffmail.com

Rec date: Jul 28, 2014; Acc date: Sep 17, 2014; Pub date: Sep 27, 2014

Copyright: @ 2014 Rai V, et al. This is an open-access article distributed under the terms of the Creative Commons Attribution License, which permits unrestricted use, distribution, and reproduction in any medium, provided the original author and source are credited.

\begin{abstract}
Drinking water Samples were collected from different localities of Lucknow city, Capital of Uttar Pradesh State, India for the estimation of Fluoride content. Boring water as well as supply water of Municipal Corporation was collected for the present study. It was found that almost all the studied samples had fluoride concentration within the acceptable limit and no substantial difference in fluoride concentration was found in all the samples except the samples from Bhola purva, Bakshi ka taalab area. Water collected from this area has more than 1.0 ppm (acceptable limit in India) of fluoride.
\end{abstract}

Keywords: Drinking water; Fluoride; Lucknow City; Acceptable Limit

\section{Introduction}

Fluorine is a naturally occurring element that does not occur in the elemental state in nature because of its high reactivity. It accounts for about $0.3 \mathrm{~g} / \mathrm{kg}$ of the Earth's crust [1] and exists in the form of fluorides in a number of minerals, of which fluorspar, cryolite and fluorapatite are the most common. The oxidation state of the fluoride ion is -1. Fluoride is ubiquitous in the environment, and, therefore, sources of drinking-water are likely to contain at least some small amount of fluoride. The amount of fluoride present naturally in drinking-water is highly variable, being dependent upon the individual geological environment from which the water is obtained. In areas rich in fluoride-containing minerals, boring water may contain up to about $10 \mathrm{mg}$ of fluoride per litre [2]. Large numbers of Indians rely on groundwater for drinking purposes and at many places this groundwater is rich in fluoride. Although fluoride is beneficial when consumed in recommended doses but excess intake may cause fluorosis including dental, skeletal and non-skeletal fluorosis along with secondary neurological complications [3-6]. In India 62 million people including 6 million children are estimated to have serious health problems due to consumption of fluoride contaminated water [7-9]. The main source of Fluoride in humans is drinking water.

Fluoride in most groundwater occurs as the anion F-. Calciumdeficient ground waters in many basement aquifers, such as granite and gneiss had high fluoride content. Groundwater with high fluoride concentrations occur in many areas of the world including large parts of Africa, China, the Middle East and southern Asia (India, Sri Lanka). One of the high fluoride belt is from Turkey through Iraq, Iran, Afghanistan, India, northern Thailand and China. The Americas and Japan also have similar belts [1].

Although drinking water is usually the largest contributor to the daily fluoride intake of humans but Fluoride is also found in vegetables, fruit, tea and other crops. The WHO guideline value for fluoride is $1.5 \mathrm{mg} /$ litre, with a target of between $0.8-1.2 \mathrm{mg} / \mathrm{l}$ to maximize benefits and minimize harmful effects. Acceptable levels depend on climate, volumes of water intake and the likely intake of fluoride from other sources [1]. Presently, seventeen Indian states have been identified as having excess fluoride in drinking water [6]. In Rajasthan, people of 22 districts are consuming fluoride greater than permissible limit [10]. Usually, the surface water does not contain as high fluoride as groundwater because the usual source of fluoride is fluoride rich rocks. When water percolates through rocks, it leaches out the fluoride from these rocks. Therefore major source of Fluoride in the groundwater is leaching from earth crust.

In India due to lack of central water supply in most of the country, groundwater is being used for drinking purposes. Fluoride levels in drinking water are also found to be low or normal in certain areas. Unfortunately, proper fluoride mapping has not been carried in India so as to locate areas with normal, low, or high levels of fluoride. Scanty work has been reported on the drinking water quality of Lucknow city, the capital of Uttar Pradesh State, India, with special focus to Fluoride. Hence in order to fill this gap the present work was initiated. The present paper analyzes the fluoride content of drinking water in Lucknow city and its probable effect on the health of the population.

\section{Materials and Methods}

Twenty different localities were selected in and around Lucknow city to collect water samples. Supply water of Municipal Corporation as well as boring water was collected from residential colonies of selected areas. Besides this Gomti river water was also collected for comparison. Name of the selected areas were as follows:

\section{Selected Areas of Lucknow for Sample Collection}

Jankipuram, Madiaon, Bhola Purva, Bakshi ka Talab, Matiyari, Chinhat, Manoj Pandey Chauraha, Vibhuti Khand, Gomti Nagar, Sadar Cantt Road, Udayganj, Aishbagh, Peeli Colony, Taal catora, Alambagh, Sardari Kheda, Hussainabad, Chhota Imambara, Nishatganj, Balda Colony, New Hyderabad, A Block, Indira Nagar, Sector 25, Indira Nagar, Gomti River.

Five- five samples of boring water and supply water were collected from each locality and all the samples were stored in sterile polypropylene containers (Corning Co.) All water samples were transported to the Prakriti Consultant Services, Lucknow for analysis. At the laboratory, technicians measured $50-\mathrm{mL}$ samples of water into 
Page 2 of 3

sterile containers, each numbered with a key retained only by the investigators. Because the laboratory technicians were blinded to the type of water contained in the samples, any potential bias was eliminated. Furthermore, as a quality control measure, $10 \%$ of all the samples were double-tested to verify results. The fluoride levels were measured by the standard method of measuring fluoride level in water as recommended by the APHA, 2005,[11] using an ion-selective electrode (Expandable Ion Analyzer; Orion Research Incorporated). Fluoride standards ranging from 0.01 to $1.00 \mathrm{mg} \mathrm{L}-1$ fluoride were used to calibrate the measurement. For satisfactory results Total Ionic Strength Adjustment Buffer (TISAB) was used to maintain a suitable ionic strength and to avoid complex formation.

TISAB II (Total Ionic Strength Adjustment Buffer), was added to the standard fluoride solutions to adjust the $\mathrm{pH}$ and to break up complexes. The instrument was calibrated with the two standard solutions. To each water sample TISAB II was added in 1:1 ratio. To determine the F- concentration, the electrode was left to stand in the solution for 3 minutes. After 3 minutes the F- concentration in the water sample was read directly from the digital display meter. For each sample, two fluoride readings were taken. $84 \%$ samples showed no difference between the two measurements. $8 \%$ of all the samples showed the difference of $0.01 \mathrm{ppm}, 2 \%$ samples showed the differences of $0.02 \mathrm{ppm}$ and $6 \%$ samples showed the differences of $0.03 \mathrm{ppm}$ respectively.

\section{Results and Discussion}

The range and mean values of fluoride in drinking water samples from supply water and boring water are shown in Table 1 . The fluoride concentrations of all the drinking water sources are higher in summer months. There is little dilution of fluoride in ground water during the rainy season.

Minimum mean fluoride concentration in supply water was found in the area of Matiyari i.e. $0.28 \mathrm{ppm}$ and maximum fluoride concentration in supply water was found in the Sadar area of Lucknow i.e. $0.58 \mathrm{ppm}$. In the case of boring water maximum fluoride concentration was found in the Bakshi ka taalab area of Lucknow District i.e. $1.56 \mathrm{ppm}$. In boring water also minimum concentration was found in Matiyari area i.e. $0.30 \mathrm{ppm}$. No substantial difference in fluoride concentration was found in all the samples except the samples of Bhola purva, Bakshi ka taalab area which has more than acceptable limit i.e.1.0 ppm [12] of fluoride. All the other studied samples had fluoride within the acceptable limit in India.

\begin{tabular}{|l|l|l|l|l|}
\hline Area & \multicolumn{3}{l}{ Boring Water } & \multicolumn{2}{l}{ Supply Water } \\
\hline & Range & Mean & Range & Mean \\
\hline Jankipuram & $0.76-0.98$ & 0.85 & $0.28-0.50$ & 0.35 \\
\hline Madiaon & $0.65-0.82$ & 0.78 & $0.30-0.55$ & 0.40 \\
\hline Bhola Purva & $0.98-1.78$ & 1.48 & -- & \\
\hline Bakshi ka Talab & $1.03-1.69$ & 1.56 & -- & 0.28 \\
\hline Matiyari & $0.23-0.45$ & 0.30 & $0.22-0.34$ & 0.39 \\
\hline Chinhat & $0.33-0.53$ & 0.42 & $0.28-0.52$ & 0.41 \\
\hline $\begin{array}{l}\text { Manoj } \\
\text { Chauraha Pandey }\end{array}$ & $0.35-0.52$ & 0.46 & $0.38-0.45$ & \\
\hline
\end{tabular}

\begin{tabular}{|l|l|l|l|l|}
\hline $\begin{array}{l}\text { Vibhuti Khand, Gomti } \\
\text { Nagar }\end{array}$ & $0.33-0.60$ & 0.48 & $0.25-0.40$ & 0.34 \\
\hline Sadar & $0.60-0.82$ & 0.72 & $0.50-0.67$ & 0.58 \\
\hline $\begin{array}{l}\text { Cantt Road, } \\
\text { Udayganj }\end{array}$ & $0.63-0.72$ & 0.68 & $0.52-0.60$ & 0.55 \\
\hline Aishbagh & $0.42-0.56$ & 0.50 & $0.20-0.33$ & 0.26 \\
\hline $\begin{array}{l}\text { Peeli Colony, Taal } \\
\text { catora }\end{array}$ & $0.40-0.61$ & 0.51 & $0.32-0.38$ & 0.33 \\
\hline Alambagh & $0.41-0.58$ & 0.53 & $0.36-0.42$ & 0.38 \\
\hline SardariKheda & $0.56-0.72$ & 0.63 & $0.40-0.54$ & 0.47 \\
\hline Hussainabad & $0.62-0.76$ & 0.69 & $0.42-0.65$ & 0.53 \\
\hline Chhota Imambara & $0.58-0.73$ & 0.67 & $0.43-0.58$ & 0.54 \\
\hline Nishatganj & $0.53-0.62$ & 0.58 & $0.38-0.51$ & 0.46 \\
\hline $\begin{array}{l}\text { Balda Colony, New } \\
\text { Hyderabad }\end{array}$ & $0.54-0.68$ & 0.61 & $0.40-0.52$ & 0.45 \\
\hline A Block,Indira Nagar & $0.54-0.67$ & 0.60 & $0.45-0.62$ & 0.53 \\
\hline $\begin{array}{l}\text { Sector 25, Indira } \\
\text { Nagar }\end{array}$ & $0.52-0.58$ & 0.54 & $0.32-0.53$ & 0.41 \\
\hline Gomti River & $0.50-0.62$ & 0.55 & & \\
\hline
\end{tabular}

Table 1: Mean fluoride values (ppm) in drinking water sources.

In this preliminary study it was found that most of the areas in Lucknow city had Fluoride level within the permissible limit. Therefore anticipated health risk of the population living here is minimum. In the area where higher level of Fluoride was found i.e. Bakshi ka Taalab area, people are vulnerable to fluoride toxicity. Although more detailed study is required for further steps. As in this area people only depend on boring water i.e. Groundwater, it is recommended therefore, that piped water should be provided to the residents for drinking purposes after proper analysis. Besides, the use of existing hand pumps and tube wells, having high fluoride content, may be restricted only for washing and bathing etc.

\section{Acknowledgment}

This work is supported by a research grant from the Science and Engineering Research Board, Department of Science and Technology, New Delhi, India, and First author is thankful to SERB for financial assistance.

\section{References}

1. WHO (1996) WHO Guidelines for drinking water quality. (2nd edn).

2. US EPA (1985) Drinking water criteria document on fluoride. Washington, DC, US Environmental Protection Agency, Office of Drinking Water (TR-823-5).

3. Indermitte E, Karro E and Saava A (2007) Tap water fluoride levels in Estonia. Fluoride 40: 244-247.

4. Lineswara Rao SV (2003) Fluoride toxicity in Raptadu mandal, Anantapura district, Andhra Pradesh, India. J. Curr. Sci. 3: 329-334.

5. Rajkumari KR and Rao RM (1985) Fluorosis in Nagaland district in relation to chemical characterization of potable water and staple food. Fluoride 18: 198-202. 
Citation: $\quad$ Rai V, Singh M (2014) Fluoride Concentration in Drinking Water of Lucknow City, India: A Case Study . Hydrol Current Res 5: 181. doi: 10.4172/2157-7587.1000181

Page 3 of 3

6. Susheela AK (1993) Prevention and control of fluorosis in India. Rajeev Gandhi National Drinking Water Mission. Health Abstract 1.

7. Susheela AK (2001) Fluorosis: Indian scienario: A treatise on fluorosis. Fluorosis Research and Rural Development Foundation; New Delhi, India.

8. Arlappa N, Aatif Qureshi I, Srinivas R. (2013) Fluorosis in India: an overview. Int J Res Dev Health 1: 97-102.

9. Kotecha PV, Patel SV, Bhalani KD, Shah D, Shah VS, et al. (2012) Prevalence of dental fluorosis \& dental caries in association with high levels of drinking water fluoride content in a district of Gujarat, India. Indian J Med Res 135: 873-877.

10. Samal UN and Naik BN (1988) Dental Fluorosis in school children in the vicinity of an Aluminium factory in India. Fluoride 21: 142-148.

11. APHA (2005) Standard methods for the examination of water and wastewater. (21st edn), American Public Health Association, New York, USA.

12. BIS (2012) Indian Standarad. Drinking water specification (second Revision). Buerau of Indian Standard. IS 10500:2012. 